\title{
Preserved tissue structure of efferent ductules in aromatase-deficient mice
}

\author{
Katsumi Toda ${ }^{1}$, Teruhiko Okada ${ }^{2}$, Yoshihiro Hayashi ${ }^{3}$ and Toshiji Saibara ${ }^{4}$ \\ Departments of ${ }^{1}$ Biochemistry, ${ }^{2}$ Anatomy and Cell Biology, ${ }^{3}$ Pathology and ${ }^{4}$ Gastroenterology and Hepatology, School of Medicine, Kochi University, Nankoku, \\ Kochi 783-8505, Japan \\ (Correspondence should be addressed to K Toda; Email: todak@kochi-u.ac.jp)
}

\begin{abstract}
Estrogen receptor $\alpha(E s r 1)$ is proposed to play a critical role in the regulation of testicular fluid reabsorption at efferent ductules, and disruption of the Esr 1 gene $\left(E s r 1^{-/}\right)$resulted in marked dilation of the lumens of efferent ductules. This study was aimed to clarify whether disruption of the gene for aromatase $(A r)$, an enzyme responsible for estrogen biosynthesis, results in morphological and transcriptional alterations at efferent ductules as observed in Esr1 ${ }^{-/-}$mice. Histology demonstrated structural preservation of the ducts in aromatase-deficient $\left(\mathrm{Ar}^{-/-}\right)$mice. Electron microscopic examinations reveal that endocytic apparatus and tubule-cisternal endoplasmic reticulum are present in non-ciliated cells irrespective of the genotypes. However, electron-dense and acid phosphatase-negative granules and apical tubules,
\end{abstract}

which are components thought to be related to membrane recycling of endosomes, are observed only in wild-type (WT) and $A r^{-/-}$mice. By contrast, the Golgi complex is highly developed in Esr ${ }^{-1-}$ mice when compared with WT and $\mathrm{Ar}^{-1-}$ mice. RT-PCR analysis reveals no significant differences in the expression levels of a subset of genes involved in ion transportation. Thus, from the structural and transcriptional points of view, the efferent ductules of $\mathrm{Ar}^{-1-}$ mice are indistinguishable from those of WT mice. Moreover, data from electron microscopic examinations indicate the possible involvement of Esr 1 in the regulation of vesicle recycling processes.

Journal of Endocrinology (2008) 199, 137-146

\section{Introduction}

Testicular development and the maintenance of spermatogenesis are controlled mainly by gonadotropins and androgens (Holdcraft \& Braun 2004). However, besides the well-known negative effect of estrogens on the secretion of gonadotropins, they have been shown to directly regulate testicular functions (Simpson et al. 1994, Carreau et al. 2006, Ebling et al. 2006). Estrogens are synthesized by an enzyme complex, aromatase, through the conversion of androgens to estrogens in Sertoli cells in immature animals and in Leydig cells in adults (Rommerts et al. 1982, Simpson et al. 1994, O'Donnell et al. 2001). Furthermore, germ cells were proposed to be one of the major sites for estrogen synthesis in adult mouse testis (Nitta et al. 1993).

Estrogens are thought normally to modulate the transcription of specific genes in estrogen target tissues through binding to estrogen receptors of either $\alpha$ - or $\beta$-subtype (Couse \& Korach 1999, Nilsson et al. 2001). Both subtypes have been reported to be expressed abundantly in the efferent ductules (Zhou et al. 2002), where a large part of testicular luminal fluid is reabsorbed to concentrate spermatozoa (Clulow et al. 1998, Hess 2000). Esr1 gene knockout $\left(E s r 1^{-/-}\right)$mice display dilation of the lumens of the efferent ductules, of which the diameter becomes more than double the size of wild-type (WT) males (Hess et al. 1997), indicating that luminal fluid is not removed causing accumulation of fluids in the lumen of the efferent and seminiferous tubules. As Esr $2^{-1-}$ mice did not display apparent morphological abnormalities in the efferent ductules (Krege et al. 1998, Antal et al. 2008) and the phenotype of Esr $1^{-1-} E s r 2^{-1-}$ mice was similar to that of Esr1 ${ }^{-/}$mice (Couse et al. 1999), Esr1 rather than Esr2 plays a major role in normal fluid reabsorption at the efferent ductules. Nevertheless, the requirement of aromatase activity for Esr 1 to function at the ducts has not been established.

Because estrogens are synthesized by aromatase in the testis, aromatase gene knockout $\left(\mathrm{Ar}^{-1-}\right)$ mice are a useful animal model to assess the testicular function of estrogens in vivo. Three lines of $\mathrm{Ar}^{-1-}$ mice have been generated independently (Fisher et al. 1998, Honda et al. 1998, Toda et al. 2001a). However, the testicular phenotypes are variable among the lines. The $\mathrm{Ar}^{-/-}$mice generated by us were nearly infertile and showed no disruptions in spermatogenesis until 10 months of age, although an apparent reduction in seminiferous epithelial height was observed at that age (Toda et al. 2001b). The $A r^{-1-}$ males generated by other group are reportedly fertile at 12-14 weeks of age and one of four $\mathrm{Ar}^{-1-}$ mice examined displayed grossly dysmorphic seminiferous tubules 
Table 1 Primer pairs used for RT-PCR

5' Primer primer

Gene

Atp1a1

Cftr

Slc9a1

Slc9a3

Gapdh

\author{
GGGGATTGTTGGCTCTGATG \\ CTGGAGGCGAAATGGTTGTC \\ GGCCAACATCTCCCACAAAT \\ GGATGAAAAGCAGGACAAGG \\ CGGATTTGGTCGTATTGG
}

3' Primer primer

Size $(b p)$

TTTGTCCGTTTTGGGGTTTC 328

TTGGTATGTTATGGGGTCTA 530

GCCTGCTTCATCTCCATCTT 651

AGGGGAGAACACGGGATTAT 343

TCCTGGAAGATGGTGATG 210 and disrupted spermatogenesis at 4.5 months of age (Robertson et al. 1999, 2001). This phenotypic heterogeneity in spermatogenesis between the $A r^{-/-}$lines seems to be attributable to differences in genetic backgrounds rather than in the genomic region used for the gene inactivation, as the neo gene was inserted at the EcoRV site in exon 9 of Cyp 19a1 for the disruption of the gene in both $A r^{-/-}$lines (Fisher et al. 1998, Toda et al. 2001a). We thus generated fully congenic $A r^{-/-}$mice with a $\mathrm{C} 57 \mathrm{BL} / 6 \mathrm{~J}$ background by repeated backcrossing to $\mathrm{C} 57 \mathrm{BL} / 6 \mathrm{~J}$ mice. This study was conducted using $A r^{-/-}$mice with a $\mathrm{C} 57 \mathrm{BL} / 6 \mathrm{~J}$ genetic background to examine the effects of aromatase inactivation on spermatogenesis and the efferent ductules with special reference to the changes observed in the tissue sites of Esr1 ${ }^{-/-}$mice.

\section{Materials and Methods}

\section{Experimental animals}

The animal experiments were carried out according to the Guidelines of our Institutional Animal Regulations. All animals were maintained on a $12 \mathrm{~h}$ light: $12 \mathrm{~h}$ darkness cycle at $22-25{ }^{\circ} \mathrm{C}$ and given water ad libitum and a chow, NIH07PLD, which was developed by the National Institute of Health (USA) in order to lower phytoestrogen contents in the chow (Oriental Yeast Co., Tokyo, Japan; Yamasaki et al. 2002). Cyp 19a1 was disrupted by homologous recombination (Toda et al. 2001a) and the genetic background was unified to C57BL/6J by repeated backcrossing. Esr $1^{+/-}$mice (Lubahn et al. 1993) were purchased from Taconic Farms, Inc. (Hudson, NY, USA) and bred in the animal facility of Kochi University to yield Esr $1^{+/-}$mice with a C57BL/6J genetic background. Esr1 ${ }^{-/-}$mice were generated by

Table 2 Summary of spermatogenic phenotype of mice with the C57BL/6J genetic background. Testes of WT, $\mathrm{Ar}^{-1-}$, and $\mathrm{Esr}^{-1-}$ mice at 5 or 10 months of age were histologically examined.

\begin{tabular}{|c|c|c|c|}
\hline \multirow{3}{*}{$\begin{array}{l}\text { Age } \\
5 \mathrm{M}\end{array}$} & WT & $\boldsymbol{A r} \boldsymbol{r}^{-1-}$ & Esr1 $^{-1-}$ \\
\hline & & & \\
\hline & $0^{\mathrm{a}} / 44^{\mathrm{b}}(0 \%)$ & $13 / 20(65 \%)$ & $14 / 14(100 \%)$ \\
\hline $10 \mathrm{M}$ & $0 / 8(0 \%)$ & $9 / 13(69 \%)$ & ND \\
\hline
\end{tabular}

${ }^{a}$ Number of mice showing spermatogenic impairment.

${ }^{\mathrm{b}}$ Number of mice examined. crossing of Esr $1^{+/-}$mice. Mice at 5 or 10 months of age were used for this study.

\section{Histological examination}

Testes and efferent ductules were fixed in a solution of $10 \%$ $(\mathrm{v} / \mathrm{v})$ buffered formalin for $24 \mathrm{~h}$, dehydrated in graded ethanol, and then embedded in paraffin. Samples were cut into $3 \mu \mathrm{m}$ thick sections and stained with hematoxylin-eosin. The luminal areas of the efferent ductules were quantified using MacScope (ver. 2.5.9) software.

\section{Electron microscopic examination}

The efferent ductules were fixed in modified Karnovsky's fixative containing $2 \%$ paraformaldehyde, $2 \%$ glutaraldehyde, and $0.05 \% \mathrm{CaCl}_{2}$ in $0.1 \mathrm{M}$ cacodylate buffer $(\mathrm{pH} 7 \cdot 2)$ for $1 \mathrm{~h}$ at $4{ }^{\circ} \mathrm{C}$. The specimens were post-fixed with $1 \%$ osmium tetroxide in $0 \cdot 1 \mathrm{M}$ cacodylate buffer $(\mathrm{pH} 7 \cdot 2)$ containing $0 \cdot 8 \%$ potassium ferrocyanide for $2 \mathrm{~h}$ in the dark to preserve the structure of tubule-cisternal endoplasmic reticulum (TCER; Møller et al. 1983). After rinsing, the specimens were exposed to en bloc stain in $1 \%$ uranyl acetate in $0.05 \mathrm{M}$ sodium maleate $(\mathrm{pH} 6 \cdot 0)$ for $1 \mathrm{~h}$ in the dark. After rinsing in $0.05 \mathrm{M}$ sodium maleate $(\mathrm{pH} 5 \cdot 0)$ for $1 \mathrm{~h}$, the specimens were dehydrated in a graded series of alcohol (Karnovsky 1967), and embedded in Spurr's resin. Thin sections were observed using a Hitachi $\mathrm{H}-7000 \mathrm{H}$ electron microscope. Acid phosphatase activity was detected by means of a cerium-based cytochemical method to identify lysosomes (Robinson et al. 1986).

\section{Western blot analysis}

The efferent ductules were kept in RNAlater (Ambion, Austin, TX, USA) at $-20^{\circ} \mathrm{C}$ until use. After removing the fat and connective tissue under a microscope, the tissues were minced using scissors and homogenized in an ice-cold homogenization buffer consisting of $50 \mathrm{mM}$ Tris- $\mathrm{HCl}$ buffer ( $\mathrm{pH} 7 \cdot 4$ ), $0 \cdot 4 \mathrm{M}$ $\mathrm{NaCl}, 0 \cdot 1 \mathrm{mM}$ EDTA, $0 \cdot 1 \mathrm{mM}$ EGTA, and protease inhibitor cocktail (Roche). The protein concentration of the homogenate was measured with a BCA protein assay reagent (Pierce, Rockford, IL, USA). Each sample $(40 \mu \mathrm{g})$ was subjected to SDS-PAGE in a $10 \%$ gel. The separated polypeptides were then transblotted onto a polyvinylidene difluoride (PVDF) membrane. After treatment with blocking agent, the membrane was incubated with anti-Esr1 antibody at a dilution of 1:2000 (MC20; Santa Cruz Biotechnology, Inc., Santa Cruz, CA, USA). 
After washing, the membrane was subsequently incubated with horseradish peroxidase (HRP)-anti-rabbit antibody and the enzyme activity of HRP was detected with an ECL western blotting detection kit. After detaching the anti-Esr1 antibody, the same membrane was reprobed with an HRP-anti- $\beta$-actin monoclonal antibody (Sigma-Aldrich, Inc). The results were quantified using Quantity One (ver. 3.0) software (PDI Inc., Huntington Station, NY, USA).

\section{$R N A$ preparation and $R T-P C R$ analysis}

Total RNA was extracted from pooled efferent ductules kept in RNA later as described (Zarlenga \& Gamble 1987) after removing fat and connective tissue under a microscope. Total RNA $(1 \mu \mathrm{g})$ was reversed transcribed using oligo-dT primers (Ambion) and Moloney murine leukemia virus reverse transcriptase (Invitrogen) in a total volume of $25 \mu \mathrm{l}$ per

A
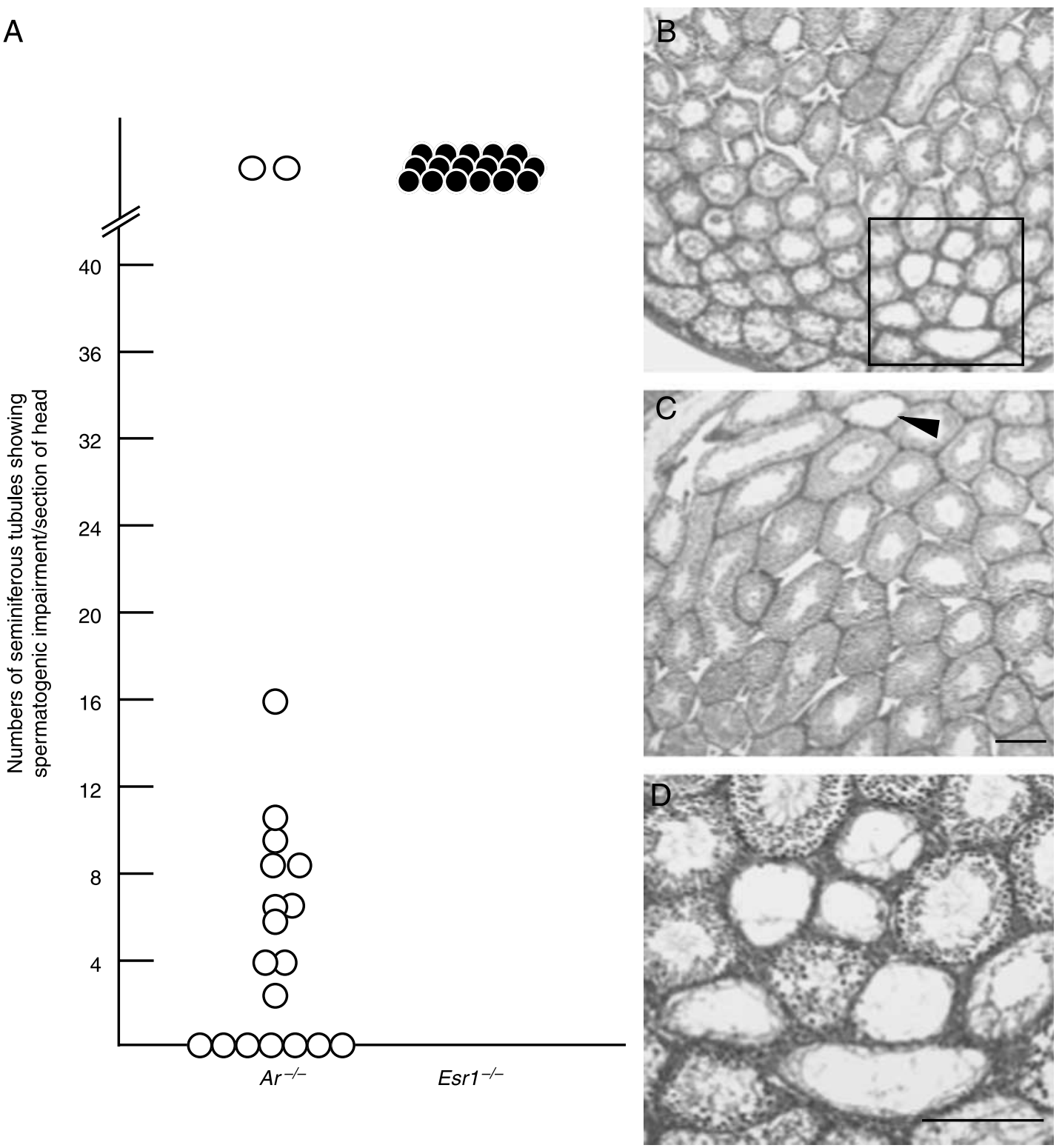

Figure 1 Histological examination of the testes of $\mathrm{Ar}^{-1-}$ and $\mathrm{Ssr}^{-1-}$ mice with a C57BL/6J genetic background. (A) Each circle represents an individual mouse, of which both testes were examined histologically. Vertical numerals indicate the sum of the numbers of seminiferous tubules showing impaired spermatogenesis per section in each mouse examined. As no abnormality was found in the testes of WT mice with a C57BL/6J background, the data were not plotted in this figure. ( $\mathrm{B}$ and $\mathrm{C}$ ) Representative photographs of the testis of an $\mathrm{Ar}^{-1-}$ mouse at 5 months of age displaying various degrees of impairment in spermatogenesis. The seminiferous tubules indicated by arrowhead in (C) are judged to be impaired.

(D) The image shown at higher magnification is from the area indicated by a box in (B). Scale bar, $200 \mu \mathrm{m}$. 
reaction, according to the manufacturer's instructions. The expression levels of genes for ATPase, $\mathrm{Na}^{+} / \mathrm{K}^{+}$transporting, $\alpha-1$ polypeptide (Atp1a1), cystic fibrosis transmembrane conductance regulator homolog (Cftr), solute carrier family 9 (sodium/hydrogen exchanger) member 1 (Slc9a1), and solute carrier family 9 (sodium/hydrogen exchanger) member 3 (Slc9a3) were examined. PCR was carried out with $1.5 \mu \mathrm{l}$ of the RT samples in a $30 \mu \mathrm{l}$ reaction volume.
Cycling parameters were as follows: an initial melting step of $94^{\circ} \mathrm{C}$ for $1 \mathrm{~min}$, amplification by 28 cycles at $94^{\circ} \mathrm{C}$ for $30 \mathrm{~s}$, $60^{\circ} \mathrm{C}$ for $30 \mathrm{~s}$, and $74{ }^{\circ} \mathrm{C}$ for $45 \mathrm{~s}$ and then a final $5 \mathrm{~min}$ at $74{ }^{\circ} \mathrm{C}$ for extension. The amplified DNA products were resolved on $5 \%$ polyacrylamide gels. After staining the gels with ethidium bromide, the banding pattern of amplified DNA fragments was recorded using a charged-coupled device camera (Sony Corp., Tokyo, Japan). The results were
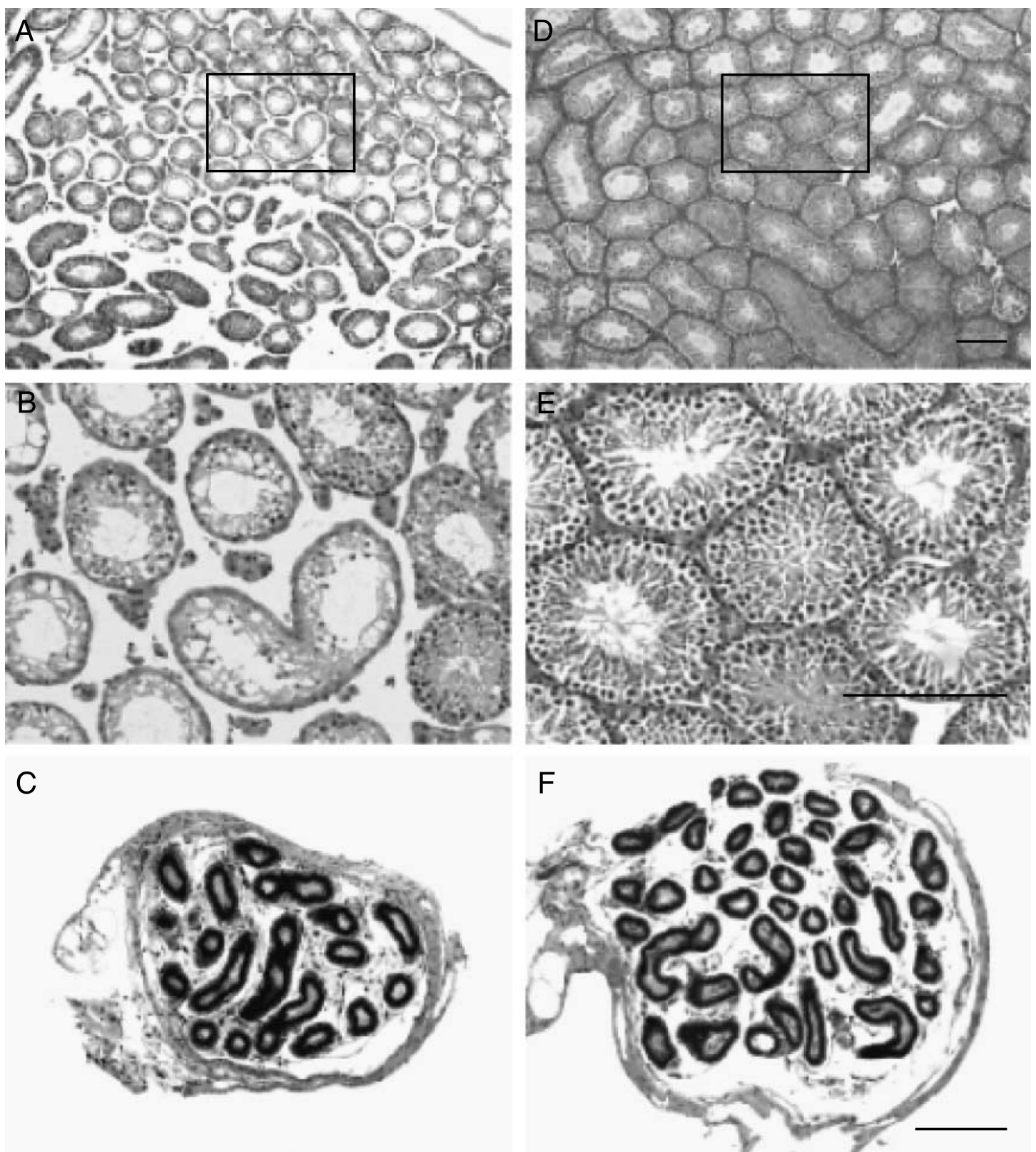

Figure 2 Photomicrographs of the testis and efferent ductules in the distal region of two individual $A r^{-1-}$ mice at 5 months of age. (A and B) Testis from one $A r^{-1-}$ mouse at 5 months of age showed spermatogenic impairment and (D and E) the testis from the other $\mathrm{Ar}^{-1-}$ mouse displayed morphologically normal spermatogenesis. ( $\mathrm{B}$ and $\mathrm{E}$ ) The images shown at higher magnification are from the areas indicated by boxes in (A) and (D) respectively. (C and F) Both $A r^{-1-}$ mice reveal similar morphology in the distal efferent ductules. Scale bars, $200 \mu \mathrm{m}$. 
quantified using Quantity One (ver. 3.0) software. The intensity values for each transcript were normalized to the respective expression level of glyceraldehyde 3-phosphate dehydrogenase (Gapdh) and expressed as fold difference over the value of WT mice. The nucleotide sequences of primers and the sizes of amplified fragments are listed in Table 1.

\section{Statistical analysis}

Data are expressed as the means \pm s.E.M. The significance of differences was analyzed using Student's $t$-test employing InStat software (GraphPad Software, Inc., San Diego, CA, USA, 2003). $P<0 \cdot 05$ was considered significant.

\section{Results}

Histological examination of the testicular phenotype of $\mathrm{Ar}^{-1-}$ mice with a C57BL/6J genetic background

Spermatogenesis was evaluated morphologically at 5 and 10 months of age by measuring the numbers of dysmorphic seminiferous tubules per section. None of the WT males displayed spermatogenetic impairment at either age (Table 2). By contrast, variable degrees of aberrant morphological features were observed in the seminiferous tubules of $A r^{-1-}$ mice with a fully congenic C57BL/6J genetic background at 5 months of age (Fig. 1A). Out of $20 \mathrm{Ar}^{-/-}$mice, 2 displayed grossly dysmorphic seminiferous tubules and disrupted spermatogenesis, and 11 mice showed variable degrees of spermatogenic impairment (Fig. 1B-D). As reported previously (Eddy et al. 1996), all of the Esr1 $1^{-/}$mice examined showed spermatogenic impairment (Fig. 1A; Table 2). When analyzed at 10 months of age, $70 \%$ of $A r^{-/-}$mice (9 out of 13 mice) showed histologically severe impairment of spermatogenesis.

\section{Morphology of efferent ductule of $\mathrm{Ar}^{-1-}$ mice}

The morphology of the efferent ductules of an $\mathrm{Ar}^{-1-}$ mouse showing impairment in spermatogenesis was indistinguishable from that of an $\mathrm{Ar}^{-1-}$ mouse showing relatively normal spermatogenesis at 5 months of age (Fig. 2). When measuring the luminal areas of the efferent ductules at the distal region, the luminal area of Esr1 ${ }^{-/-}$mice at 5 months of age was twofold larger than that of WT mice $\left(E s r 1^{-1-}, 92 \cdot 6 \pm 6 \cdot 5 \mu \mathrm{m}^{2}\right.$; WT, $42 \cdot 5 \pm 2.9 \mu \mathrm{m}^{2} ; P<0 \cdot 001$; Fig. 3$)$, which is consistent with
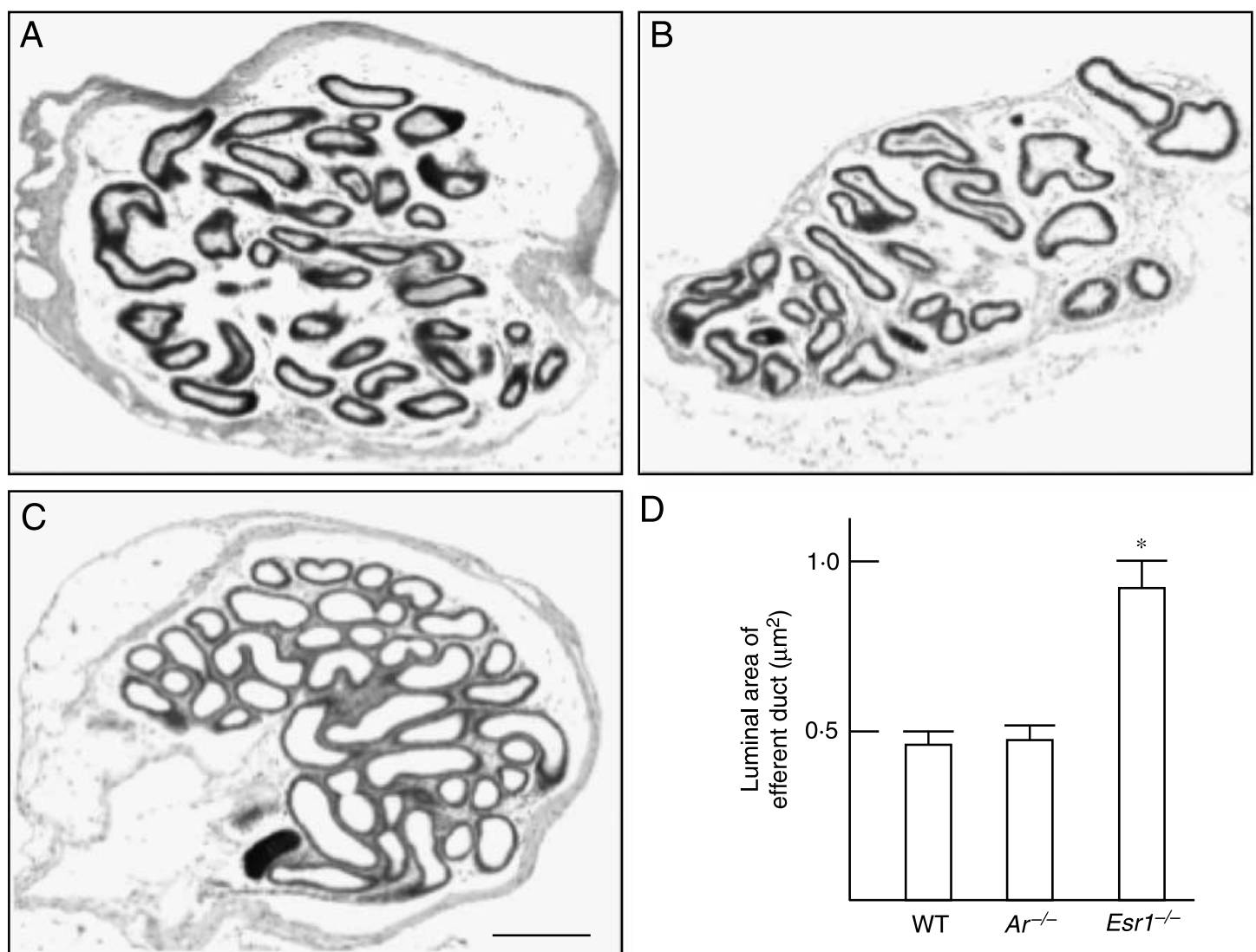

Figure 3 Photomicrographs of the distal region of the efferent ductules and the luminal areas of the efferent ductules. Distal efferent ductules of (A) WT and (B) $A r^{-1-}$ mice showed similar morphology, but those of (C) Esr1 ${ }^{-1-}$ mice were dilated. (D) The luminal area of the $\mathrm{Esr}^{-1-}$ efferent ductules was significantly larger than those of WTand $A r^{-1-}$ mice. Scale bar, $200 \mu \mathrm{m}$. 
the previous study (Hess et al. 1997). By contrast, no significant difference was detected between $A r^{-1-}$ and WT mice $\left(A r^{-1-}, 41 \cdot 0 \pm 2 \cdot 6 \mu \mathrm{m}^{2}\right.$; WT, $42 \cdot 5 \pm 2 \cdot 9 \mu \mathrm{m}^{2}$; Fig. 3). In addition, there was no difference in the area at 10 months of age between WT and $\mathrm{Ar}^{-1-}$ mice (WT, $59 \cdot 2 \pm 7 \cdot 8 \mu \mathrm{m}^{2} ; \mathrm{Ar}^{-1-}$, $\left.54.5 \pm 6.6 \mu^{2}\right)$, while the area was significantly enlarged in Esr $1^{-1-}$ mice $\left(93.9 \pm 5.6 \mu^{2}, P<0 \cdot 001\right)$. Furthermore, the height of epithelial cells was similar between WT and $\mathrm{Ar}^{-1-}$ mice at 5 months of age (data not shown), while the height was decreased in Esr $1^{-1-}$ mice (Fig. 4A and B).

\section{Electron microscopic examinations}

The lumen of the efferent ductule is covered with a single layer of columnar epithelium that is composed of ciliated and nonciliated cells. Non-ciliated cells had many electron-dense granules ( $\sim 1000 \mathrm{~nm}$ in diameter) at the supranuclear and basal cytoplasm in WT and $\mathrm{Ar}^{-/-}$but not in $\mathrm{Esr}^{-/}$mice (Fig. 4A and B). Cytochemical analysis for detecting acid phosphatase activity demonstrated that the granules were totally negative for the activity, indicating that they were not lysosomes (Fig. 4C).
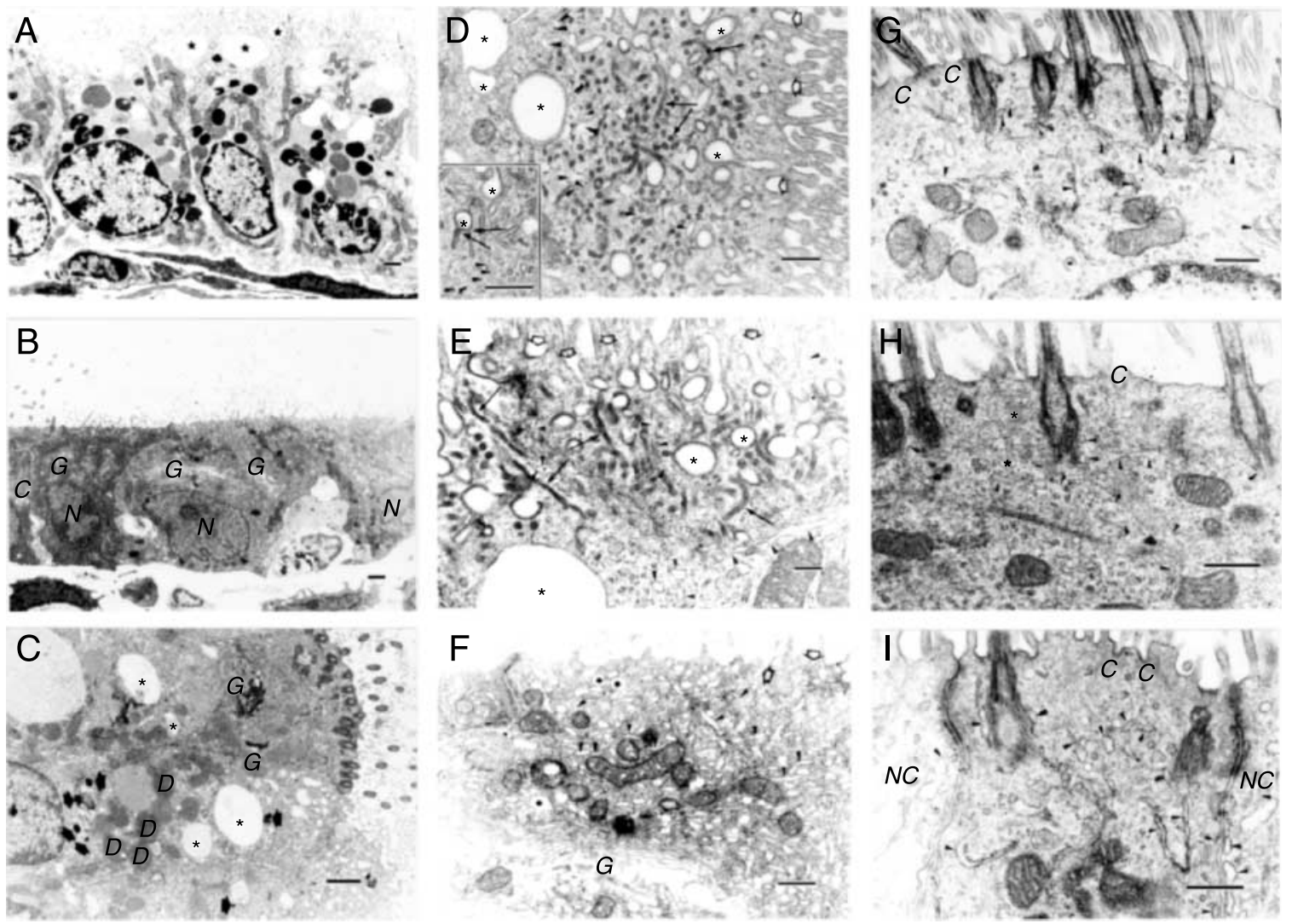

Figure 4 Transmission electron micrograph analysis of the efferent ductule. Electron micrographs of the epithelium of (A, C, D, and G) WT, (E and H) $A r^{-I-}$, and (B, F, and I) $E s r 1^{-1-}$ efferent ductules. (A) Non-ciliated epithelial cells of the WT efferent ductule have many electron-dense granules and vacuolar endosomes (asterisk). (B) Non-ciliated epithelial cells of the Esr1 ${ }^{-1-}$ efferent ductule have well-developed Golgi complex (G) but do not have electron-dense granules. $\mathrm{N}$ and $\mathrm{C}$ indicate non-ciliated and ciliated epithelial cells respectively. (C) Acid phosphatase activity was detected cytochemically in epithelial cells of the WT efferent ductules. The reaction products of acid phosphatase are observed at the Golgi complex of the ciliated cells (G) and lysosomes of the non-ciliated cells (large arrow). (D) Electron-dense granules are totally negative for staining. Endosomes are indicated by asterisks. (D) The apical part of a non-ciliated cell of the WT efferent ductules reveals the presence of a welldeveloped apical tubule (AT) (representatives indicated by arrows), vacuolar endosomes (asterisks), intermicrovillous membrane invaginations (open arrows), and a tubule-cisternal endoplasmic reticulum (TCER) (arrowheads). An insert shows endosomes connecting to the AT. (E) The apical part of a non-ciliated cell of the $A r^{-1-}$ efferent ductules reveals a similar ultrastructure to that of WT mice. (F) The apical part of a non-ciliated cell of the $E s r 1^{-1-}$ efferent ductules reveals vacuolar endosomes (asterisks) and TCER (arrowheads). The Golgi complex $(\mathrm{G})$ is well developed but the AT is not in a non-ciliated cell of the Esr1 ${ }^{-1-}$ efferent ductule. (G) The apical part of a ciliated cell of the WT efferent ductule reveals the presence of well-developed TCER (arrowheads). C indicates coated invagination. $(\mathrm{H})$ The apical part of a ciliated cell of the $\mathrm{Ar}^{-1-}$ efferent ductule reveals welldeveloped TCER as seen in that of WT mice. C indicates coated invagination. (I) The apical part of a ciliated cell of the Esr1 ${ }^{-1-}$ efferent ductule reveals well-developed TCER. C indicates coated invagination. NC indicates a non-ciliated cell. Scale bars, (A-C) $1 \mu \mathrm{m}$ and (D-I) $0.5 \mu \mathrm{m}$. 
Three types of tubule-vesicular components were observed by transmission electron microscopy. One is a component belonging to an endocytic apparatus including intermicrovillous membrane invaginations that are decorated with clathrin coat lining over the cytoplasmic surface of the invaginating region, clathrin-coated vesicles, and vacuolar early sorting endosomes (Hatae et al. 1986a). This component was observed in the WT, $A r^{-/-}$, and Esr1 $1^{-/-}$efferent ductules (Fig. 4B-I), while the sizes of the invaginations and early sorting endosomes were smaller in non-ciliated cells of Esr $1^{-/-}$mice relative to those in $\mathrm{WT}$ and $A r^{-/-}$mice (Fig. 4D-F). The second component was TCER that is well developed in ciliated cells (Fig. 4G-I) but not so prominent in non-ciliated cells (Fig. 4D-F). The third component was referred to as an apical tubule (AT), which had a cylindrical structure with a diameter raging from 60 to $80 \mathrm{~nm}$ and its lumen was filled with moderately electron-dense materials (Fig. 4D and E). Furthermore, it appeared to be covered with smooth membranous materials and occasionally connected to endocytic vesicles with a diameter ranging from 140 to $200 \mathrm{~nm}$ (Fig. 4D, insert). The AT was present densely in the apical part of non-ciliated cells of WT and $A r^{-/-}$mice, but completely absent in Esr $1^{-/-}$mice (Fig. 4D-F). Another noticeable feature was the Golgi complex, which was highly developed in the non-ciliated cells of Esr1 $1^{-/}$mice but was not prominent in those of WT and $\mathrm{Ar}^{-/-}$mice (Fig. 4B and F).

\section{Western blot and RT-PCR analyses}

The expression level of Esr1 in the efferent ductules was examined by western blotting. The antibody against Esr1 recognized a $67 \mathrm{kDa}$ protein as a main band in the extracts of efferent ductules of WT and $A r^{-/-}$mice, but not in Esr1 ${ }^{-1-}$ mice. In addition to the band, the antibody detected several minor bands, which might represent truncated forms of Esr1, degradation products, or non-specific bands. Nonetheless, the patterns of the bands were essentially the same between the samples of WT and $A r^{-/-}$mice (Fig. 5A). Furthermore, the expression level of the main band was not different between WT and $A r^{-1-}$ efferent ductules (Fig. 5B). These findings demonstrated that ESR1 protein was not overexpressed in $A r^{-1-}$ efferent ductules. Suppression of gene expressions related to ion transportation including $\operatorname{Sl} \mathrm{C}_{a} 3 \mathrm{~h}$ has been reported to be one of the reasons for impaired testicular fluid reabsorption at the efferent ductules in Esr $1^{-/-}$mice (Lee et al. 2001, Zhou et al. 2001). Therefore, we examined the expression levels of a subset of genes involved in ion transportation by a semiquantitative RT-PCR procedure. As shown in Fig. 6, no significant differences were found in the expression levels of genes for Atp1a1, Cftr, Slc9a1, and Slc9a3 between WT and $A r^{-/-}$ efferent ductules. By contrast, the expression levels of Cftr and Slc $9 a 1$ respectively increased $1 \cdot 8$ - and $2 \cdot 4$-fold and those of Slc $9 a 3$ decreased to $30 \%$ in $E s r 1^{-1-}$ efferent ductules when compared with those in WT mice (Fig. 6).
A

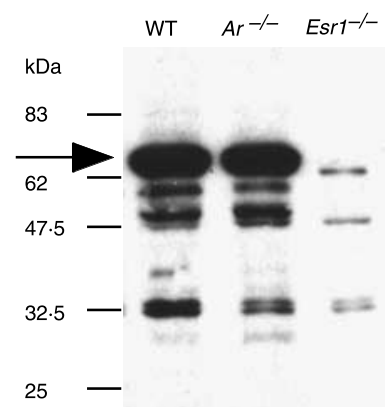

Anti-ESr1

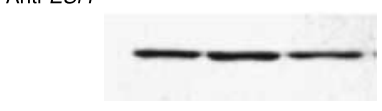

Anti- $\beta$-actin

B

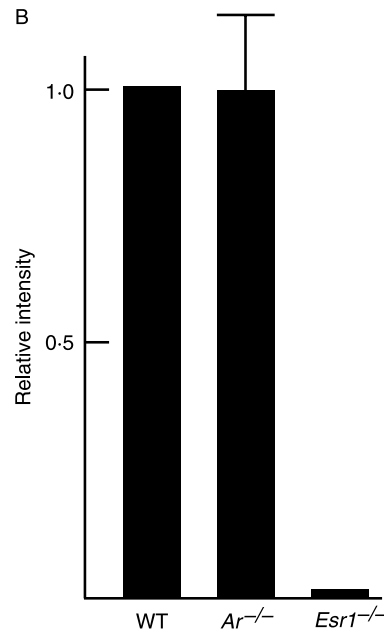

Figure 5 Western blot analysis of ESR1 protein. (A) Esr1 expression was analyzed in the efferent ductules of WT, $\mathrm{Ar}^{-1-}$, and $\mathrm{Esr}^{-1-}$ mice at 5 months of age. Gels were loaded with $40 \mu \mathrm{g}$ protein per lane. Filters were stained with anti-Esr1 antibody (upper panel) or with anti- $\beta$-actin antibody (lower panel). In addition to the main band (indicated by an arrow), several minor bands were detected by the antibody. (B) Bar graph illustrates fold differences in the expression level of the main band detected by anti-Esr1 antibody, which is indicated by an arrow in (A), in comparison with that of the WT efferent ductules. Normalization of the band was done using the signals obtained with the anti- $\beta$-actin antibody.

\section{Discussion}

$A r^{-/-}$mice with a fully congenic C57BL/6J genetic background were infertile and displayed progressive disruption in spermatogenesis. The $A r^{-/-}$mice used in the previous study displayed a more moderate spermatogenic phenotype than that of the present line (Toda et al. 2001b). This difference might reflect an effect of estrogenic compounds in the diet as reported (Robertson et al. 2002), since the current mice were fed a phytoestrogen-lowered diet (NIH-07PLD) instead of a conventional chow diet (NMF; Oriental Yeast Co.) Alternatively, the current strain with a $\mathrm{C} 57 \mathrm{BL} / 6 \mathrm{~J}$ genetic background might contain subsets of genes that are critical for maintaining normal spermatogenesis and are highly susceptible to aromatase inactivation. The data presented here indicate that aromatase activity is involved in maintaining spermatogenesis in mice; nevertheless, the molecular basis has not been established. It was reported that round spermatids showing apoptosis were detected more frequently in the seminiferous tubules of $A r^{-/-}$than WT mice (Robertson et al. 1999, 2001), suggesting that aromatase inactivation results in an increase in apoptosis-inducing molecules. Instead, estrogens might act as a potent inhibitor of apoptosis (Ebling et al. 2000, Pentikainen et al. 2000, Thuillier et al. 2003, Wang et al. 2004, Wahlgren et al. 2008), but a number of studies reported that estrogens or estrogenic compounds act as an apoptotic inducer on male germ cells (Koji 2001).

We provided experimental evidence to show that the morphological features of the efferent ductules of $A r^{-1-}$ 
A

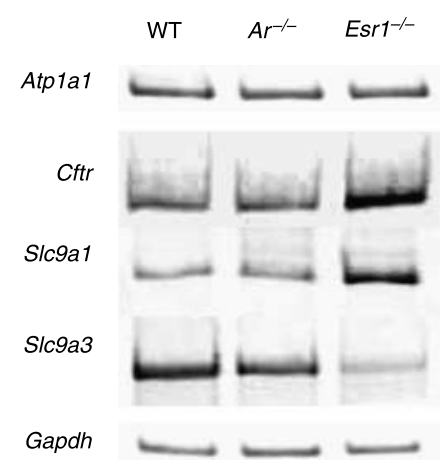

B Atp1a1 Cftr Slc9a1 Slc9a3
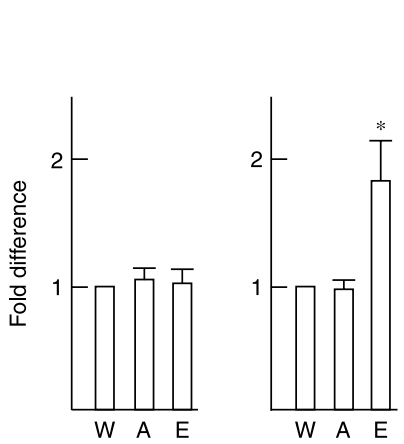

these cellular structures appeared to be smaller in Esr $1^{-/-}$ than WT and $\mathrm{Ar}^{-/-}$mice. These observations are somewhat inconsistent with the previous studies, in which endocytic apparatus including apical vesicles was markedly reduced in Esr ${ }^{-/-}$mice (Hess et al. 2000). The most striking feature is the almost complete absence of the AT in the efferent ductules of Esr $1^{-/-}$mice. The AT is frequently observed in epithelial cells of tissues such as kidney proximal tubule and visceral yolk sac (Hatae et al. 1986b) where fluids are actively absorbed. Although the roles of the AT have not been established, it was proposed that the components may be related to a membrane recycling process, by which intracellular membrane components are returned to the plasma membrane (Hatae et al. 1986b). Thus, the present findings indicate that membrane recycling activity might be compromised in the Esr1 ${ }^{-/-}$ efferent ductules leading to the low activity of fluid reabsorption. The well-developed Golgi complex observed in the Esr1 $1^{-/-}$efferent ductules might reflect the aberrant activity of membrane recycling. Involvement of Esr1/ estrogen in maintaining the apical cytoarchitecture of nonciliated epithelial cells of the efferent ductules was pointed out previously (Zhou et al. 2001).

Several lines of evidence provide clues regarding the less profound effects of aromatase inactivation on the efferent ductule, namely 1) ER ligands other than estrogens might be produced endogenously in an aromatase-independent manner (Weihua et al. 2002, McCarthy et al. 2007), 2) Esr1 is activated estrogen independently by other signaling pathways triggered by growth factors or cAMP (Julie et al. 2001, Aguirre et al. 2007). It is also of interest to speculate that exposure of $\mathrm{Ar}^{-/-}$mice to maternal estrogen during development in the uterus or during weaning through milk might affect the architecture of the efferent ductules or that aromatase inactivation might cause less active fluid secretion. Fluid reabsorption could be mediated by various aquaporins. Expressions of aquaporin 1, 9, and 10 were detected in the efferent ductules (Huang et al. 2006), of which the former two might be regulated by estrogen in the tissue (Ruz et al. 2006), suggesting that fluid reabsorption activity is affected by the expression levels of the aquaporins. Further studies will clarify the causative molecular events occurring in the $\mathrm{Ar}^{-1-}$ mice, which could promote our understanding of the actions of estrogenic compounds in the male gonadal tissues.

\section{Declaration of interest}

The authors declare that there is no conflict of interest that could be perceived as prejudicing the impartiality of the research reported.

\section{Funding}

This study was supported in part by a grant from The Long-Range Research Initiative Project of Japan Chemical Industry Association to K Toda and by a grant in aid for Scientific Research from the Ministry of Education, Culture, Sports, Science and Technology, Japan to T. Saibara. 


\section{References}

Aguirre JI, Plotkin LI, Gortazar AR, Millan MM, O'Brien CA, Manolagas SC \& Bellido T 2007 A novel ligand-independent function of the estrogen receptor is essential for osteocyte and osteoblast mechanotransduction. Journal of Biological Chemistry 282 25501-25508.

Antal MC, Krust A, Chambon P \& Mark M 2008 Sterility and absent of histopathological defects in nonreproductive organs of a mouse ER $\beta$-null mutant. PNAS 105 2433-2438.

Carreau S, Delalande C, Silandre D, Bourguiba S \& Lambard S 2006 Aromatase and estrogen receptors in male reproduction. Molecular and Cellular Endocrinology 246 (Supplement) 65-68.

Clulow J, Jones RC, Hansen LA \& Man SY 1998 Fluid and electrolyte reabsorption in the ductuli efferentes testis. Journal of Reproduction and Fertility 53 1-14.

Couse JF \& Korach KS 1999 Estrogen receptor null mice: what have we learned and where will they lead us? Endocrine Reviews 20 358-417.

Couse JF, Hewitt SC, Bunch DO, Sar M, Walker VR, Davis BJ \& Korach KS 1999 Postnatal sex reversal of the ovaries in mice lacking estrogen receptors $\boldsymbol{\alpha}$ and $\beta$. Science $2862328-2331$.

Ebling FJP, Brooks AN, Cronin AS, Ford H \& Kerr JB 2000 Estrogenic induction of spermatogenesis in the hypogonadal mouse. Endocrinology 141 2861-2869.

Ebling FJ, Nwagwu MO, Baines H, Myers M \& Kerr JB 2006 The hypogonadal (hpg) mouse as a model to investigate the estrogenic regulation of spermatogenesis. Human Fertility 9 127-135.

Eddy EM, Washburn TF, Bunch DO, Goulding EH, Gladen BC, Lubahn DB \& Korach KS 1996 Targeted disruption of the estrogen receptor gene in male mice causes alteration of spermatogenesis and infertility. Endocrinology 137 4796-4805.

Fisher CR, Graves KH, Parlow AF \& Simpson ER 1998 Characterization of mice deficient in aromatase (ArKO) because of targeted disruption of the Cyp19 gene. PNAS 95 6965-6970.

Forge A 1982 A tubulo-cisternal endoplasmic reticulum system in the potassium transporting marginal cells of the stria vascularis and effects of the ototoxic diuretic ethacrynic acid. Cell and Tissue Research 226 375-387.

Hatae T, Fujita M, Sagara H \& Okuyama K 1986a Formation of apical tubules from large endocytic vacuoles in kidney proximal tubule cells during absorption of horseradish peroxidase. Cell and Tissue Research 246 271-278.

Hatae T, Fujita M \& Sagara H $1986 b$ Helical structure in the apical tubules of several absorbing epithelia, kidney proximal tubule, visceral yolk sac and ductuli efferentes. Cell and Tissue Research 244 39-46.

Hess RA 2000 Oestrogen in fluid transport in efferent ducts of the male reproductive tract. Reviews of Reproduction 5 84-92.

Hess RA, Bunick D, Lee KH, BahrJ, Taylor JA, Korach KS \& Lubahn DB 1997 A role for oestrogens in the male reproductive system. Nature 390 509-512.

Hess RA, Bunick D, Lubahn DB, Zhou Q \& Bouma J 2000 Morphological changes in efferent ductules and epididymis in estrogen receptor- $\alpha$ knockout mice. Journal of Andrology 21 107-121.

Holdcraft RW \& Braun RE 2004 Hormonal regulation of spermatogenesis. International Journal of Andrology 27 335-342.

Honda S, Harada N, Ito S, Takagi Y \& Maeda S 1998 Disruption of sexual behavior in male aromatase-deficient mice lacking exons 1 and 2 of the cyp 19 gene. Biochemical and Biophysical Research Communications 252 445-449.

Huang H, He R, Sun C, Zhang Y, Meng Q \& Ma Y 2006 Function of aquaporins in female and male reproductive systems. Human Reproduction Update 12 785-795.

Julie M, Hall JM, Couse JF \& Korach KS 2001 The multifaceted mechanisms of estradiol and estrogen receptor signaling. Journal of Biological Chemistry 276 36869-36872.

Karnovsky MJ 1967 The ultrastructural basis of capillary permeability studied with peroxidase as a tracer. Journal of Cell Biology 35 213-236.

Koji T 2001 Male germ cell death in mouse testes: possible involvement of Fas and Fas ligand. Medical Electron Microscopy 34 213-222.

Krege JH, Hodgin JB, Couse JF, Enmark E, Warner M, Mahler JF, Sar M, Korach KS, Gustafsson JA \& Smithies O 1998 Generation and reproductive phenotypes of mice lacking estrogen receptor $\beta$. PNAS 95 15677-15682.
Lee KH, Finnigan-Bunick C, Bahr J \& Bunick D 2001 Estrogen regulation of ion transporter messenger RNA levels in mouse efferent ductules are mediated differentially through estrogen receptor (ER) $\alpha$ and ER $\beta$. Biology of Reproduction 65 1534-1541.

Lubahn DB, Moyer JS, Golding TS, Couse JF, Korach KS \& Smithies O 1993 Alteration of reproductive function but not prenatal sexual development after insertional disruption of the mouse estrogen receptor gene. PNAS $\mathbf{9 0}$ 11162-11166.

McCarthy TL, Hochberg RB, Labaree DC \& Centrella M 2007 3-ketosteroid reductase activity and expression by fetal rat osteoblasts. Journal of Biological Chemistry 282 34003-34012.

Møller OJ, Østergaard Thomsen O \& Larsen JA 1983 The existence of tubulo-cisternal endoplasmic reticulum in rat hepatocytes. Cell and Tissue Research 228 13-20.

Møllgård K \& Rostgaard J 1978 Morphological aspects of some sodium transporting epithelia suggesting a transcellular pathway via elements of endoplasmic reticulum. Journal of Membrane Biology 40 71-89.

Nilsson S, Mäkelä S, Treuter E, Tujague M, Thomsen J, Andersson G, Enmark E, Pettersson K, Warner M \& Gustafsson JA 2001 Mechanisms of estrogen action. Physiological Reviews 81 1535-1565.

Nitta H, Bunick D, Hess RA, Janulis L, Newton SC, Millette CF, Osawa Y, Shizuta Y, Toda K \& Bahr JM 1993 Germ cells of the mouse testis express P450 aromatase. Endocrinology 132 1396-1401.

O'Donnell L, Robertson KM, Jones ME \& Simpson ER 2001 Estrogen and spermatogenesis. Endocrine Reviews 22 289-318.

Pentikainen V, Erkkila K, Suomalainen L, Parvinen M \& Dunkel L 2000 Estradiol acts as a germ cell survival factor in the human testis in vitro. Journal of Clinical Endocrinology and Metabolism 85 2057-2067.

Robertson KM, O'Donnell L, Jones MEE, Meachem JS, Boon WC, Fisher CR, Graves KH, McLachlan RI \& Simpson ER 1999 Impairment of spermatogenesis in mice lacking a functional aromatase (Cyp19) gene. PNAS 96 7986-7991.

Robertson KM, Simpson ER, Lacham-Kaplan O \& Jones MEE 2001 Characterization of the fertility of male aromatase knockout mice. Journal of Andrology 22 825-830.

Robertson KM, O'Donnell L, Simpson ER \& Jones MEE 2002 The phenotype of the aromatase knockout mouse reveals dietary phytoestrogens impact significantly on testis function. Endocrinology 143 2913-2921.

Robinson JM, Okada T, Castellot JJ \& Karnovsky MJ 1986 Unusual lysosomes in aortic smooth muscle cells: presence in living and rapidly frozen cells. Journal of Cell Biology 102 1615-1622.

Rommerts FF, de Jong FH, Brinkmann AO \& van der Molen HJ 1982 Development and cellular localization of rat testicular aromatase activity. Journal of Reproduction and Fertility 65 281-288.

Ruz R, Gregory M, Smith CE, Cyr DG, Lubahn DB, Hess RA \& Hermo L 2006 Expression of aquaporins in the efferent ductules, sperm counts, and sperm motility in estrogen receptor-alpha deficient mice fed lab chow versus casein. Molecular Reproduction Development 73 226-237.

Simpson ER, Mahendroo MS, Means GD, Kilgore MW, Hinshelwood MM, Graham-Lorence S, Amarneh B, Ito Y, Fisher CR, Michael D et al. 1994 Aromatase cytochrome P450, the enzyme responsible for estrogen biosynthesis. Endocrine Reviews 15 342-355.

Thuillier R, Wang Y \& Culty M 2003 Prenatal exposure to estrogenic compounds alters the expression pattern of platelet-derived growth factor receptors alpha and beta in neonatal rat testis: identification of gonocytes as targets of estrogen exposure. Biology of Reproduction 68 867-880.

Toda K, Takeda K, Okada T, Akira S, Saibara T, Kaname T, Yamamura K, Onishi S \& Shizuta Y 2001a Targeted disruption of the aromatase P450 gene (Cyp19) in mice and their ovarian and uterine responses to 17ß-oestradiol. Journal of Endocrinology 170 99-111.

Toda K, Okada T, Takeda K, Akira S, Saibara T, Shiraishi M, Onishi S \& Shizuta Y $2001 b$ Oestrogen at neonatal stage is critical for reproductive ability of male mice as revealed by supplementation with $17 \beta$-oestradiol to aromatase (CYP19) gene knockout mice. Journal of Endocrinology 168 455-463.

Wahlgren A, Svechnikov K, Strand ML, Jahnukainen K, Parvinen M, Gustafsson JA \& Söder O 2008 Estrogen receptor beta selective ligand 5alpha-androstane3beta, 17beta-diol stimulates spermatogonial deoxyribonucleic acid synthesis in rat seminiferous epithelium in vitro. Endocrinology 149 2917-2922. 
Wang Y, Thuillier R \& Culty M 2004 Prenatal estrogen exposure differentially affects estrogen receptor-associated proteins in rat testis gonocytes. Biology of Reproduction 71 1652-1664.

Weihua Z, Lathe R, Warner M \& Gustafsson JA 2002 An endocrine pathway in the prostate, ERB, AR, 5-androstane-3B, 17B-diol, and CYP7B1 regulates prostate growth. PNAS 99 13589-13594.

Yamasaki K, Sawaki M, Noda S, Wada T, Hara T \& Takatsuki M 2002 Immature uterotrophic assay of estrogenic compounds in rats given diets of different phytoestrogen content and the ovarian changes with ICI 182,780 or antide. Archives of Toxicology 76 613-620.

Zarlenga DS \& Gamble HR 1987 Simultaneous isolation of preparative amounts of RNA and DNA from Trichinella spiralis by cesium trifluoroacetate isopycnic centrifugation. Analytical Biochemistry 162 $569-574$.
Zhou Q, Clarke L, Nie R, Carnes K, Lai LW, Lien YH, Verkman A, Lubahn D, Fisher JS, Katzenellenbogen BS et al. 2001 Estrogen action and male fertility: roles of the sodium/hydrogen exchanger-3 and fluid reabsorption in reproductive tract function. PNAS 98 14132-14137.

Zhou Q, Nie R, Prins GS, Saunders PT, Katzenellenbogen BS \& Hess RA 2002 Localization of androgen and estrogen receptors in adult male mouse reproductive tract. Journal of Andrology 23 870-881.

Received in final form 16 July 2008

Accepted 21 July 2008

Made available online as an Accepted Preprint 24 July 2008 